\title{
Antioxidant and Cytotoxic Bioassay on Blumeodendron toxbrai (Blume.) Stem Bark Hexane, Dichloromethane, and Methanolic Ekstract
}

\author{
Andreas Susilo Adi ${ }^{1, *}$, Berna Elya ${ }^{1}$, Muhammad Hanafi, M.Sc ${ }^{2}$
}

Andreas Susilo Adi ${ }^{1 *}$, Berna Elya ${ }^{1}$, Muhammad Hanafi, M.Sc ${ }^{2}$

'Faculty of Pharmacy, University of Indonesia, Depok 16424 West Java, INDONESIA.

${ }^{2}$ Research Center for Chemistry, Indonesian Institute of Sciences, Kawasan PUSPITEK Serpong, Tangerang Selatan, Banten, INDONESIA.

\section{Correspondence}

Andreas Susilo Adi

Faculty of Pharmacy, University of Indonesia, Depok 16424 West Java, INDONESIA.

E-mail: adi.andreas31@gmail.com

History

- Submission Date: 01-08-2020;

- Review completed: 07-09-2020;

- Accepted Date: 22-09-2020.

DOI : 10.5530/pj.2021.13.19

Article Available online

http://www.phcogj.com/v13/i1

Copyright

(C) 2021 Phcogj.Com. This is an openaccess article distributed under the terms of the Creative Commons Attribution 4.0 International license.

\begin{abstract}
Introduction Blumeodendron toksbraii has the potential to be anti-HIV and anti $\alpha$-glucosidase Objective: This research was conducted to examine the effects of antioxidant and cytotoxicity in vitro from these compounds from methanolic stem bark extract. Method: Stem bark to be extracted with maceration using hexane, dichloromethane, and methanol solution. Extracts were quantified with respect to in vitro antioxidant activity using the 2.2-diphenyl-1picrylhydrazyl (DPPH) radical scavenging. Anticytotoxic activity was determined by cytotoxicity assay using MCF-7 cell line with Alamar Blue method. Results: The observed IC $\mathrm{C}_{50}$ value from hexane, dichloromethane, and methanol extract for antioxidant assay were $88.33 \pm 0.19 \mu \mathrm{g} /$ $\mathrm{mL}, 74,54 \pm 0,61 \mu \mathrm{g} / \mathrm{mL}$ and $94.1 \pm 0.19 \mu \mathrm{g} / \mathrm{mL}$ respectively. $\mathrm{IC}_{50}$ value of anti-cytotoxic assay from hexane extract, dichloromethane and methanol extract is $121.24 \pm 0.15 \mu \mathrm{g} / \mathrm{mL}, 55 \pm 0,48$ $\mu \mathrm{g} / \mathrm{mL}$ and $70.71 \pm 0.15 \mu \mathrm{g} / \mathrm{mL}$. Conclusion: dichloromethane extract showed good promising result for anti-oxidant and cytotoxic assay, futher study needed to isolate compound from this plant.
\end{abstract}

Key Words: Blumeodendron toksbraii, Cancer, Antioxidant, Anticytotoxic DPPH, MCF-7.

\section{INTRODUCTION}

Cancer is the most prevalence disease in the world. The number of cancer sufferers has increased worldwide. WHO data reports that there were 8.8 million of cancer sufferers in 2015. This increase is due to the widespread pollution of waste that has the potential as a carcinogen, UV intensity, and unhealthy lifestyles such as cigarettes and alcohol ${ }^{1}$

Cancer treatments have used surgery, radiation, chemotherapy, hormonal therapy, and monoclonal antibodies. Surgery of body tissues contained in cancer cells is the first treatment for some cancer sufferers, but this is effective if done in early-stage cancer. The use of chemotherapy can also be an effective treatment option for treating cancer. So far, the chemotherapy drugs in circulation have come from synthetic drugs. Synthetic drugs are derived from natural materials such as the discovery of taxol from the Pacific Pine plant, vincristine from tread (Catharanthus roseus), and doxorubicin from soil bacterial species ${ }^{2}$.

Blumeodendron toksbrai is a woody plant that can be found in Borneo. The plant is known to contain alkaloids, terpenoids, saponin and glycosides after phytochemical screening is carried out on these plants. Currently these plants have the potential to be anti-HIV ${ }^{3}$. The only known bioassay property from this plant is anti a-glucosidase conducted by Elya dkk. which shown promising activity ${ }^{4}$.This research was conducted to examine the effects of antioxidant and cytotoxicity in vitro from these compounds from three solvent with increased polarity stem bark extract.

\section{MATERIAL AND METHOD}

\section{Sample preparation}

Stem bark of Blumeodendron toksbrai 1000 grams were collected from Bogor Botanical Garden,Bogor . The stem bark were dried then crushed to be fine powder.

\section{Extraction}

The extraction process was done by maceration method. $1 \mathrm{~kg}$ of dried bark, the bark powder is then extracted with hexane solvent to obtain hexane extract. The remaining residue was extracted with dichloromethane $(1.5 \mathrm{~L} / \mathrm{kg})$ solvent to obtain dichloromethane extract. Then the remaining residue was macerated again with methanol so as to obtain methanol extract with a vaccum rotary evaporator.

\section{Antioxidant assay}

DPPH free radical scavenging activity was conducted according to Yen and Che ${ }^{5}$. Sample was dissolved in methanol $(4 \mathrm{mg} / \mathrm{mL}), 5 \mu \mathrm{L}$ sample was pipette into the microplate. Methanolic $1 \mathrm{mM}$ DPPH solution $(40 \mu \mathrm{L})$ was added to the sample solution, then 155 $\mu \mathrm{L}$ methanol was added to give final concentration of the sample was $100 \mu \mathrm{g} / \mathrm{mL}$. The sample was measured at $515 \mathrm{~nm}$

\section{Cytotoxic assay}

Breast cancer cell line MCF-7 was obtained from Dr. Churiah (LAPTIAB-BPPT) and maintained in RCChemLIPI). The cell lines were cultivated at $37^{\circ} \mathrm{C}$ with $5 \% \mathrm{CO}_{2}$ in RPMI60 or DMEM (GIBCO)

Cite this article: AAdi AS, Elya B, Hanafi M. Antioxidant and Cytotoxic Bioassay on Blumeodendron toxbrai (Blume.) Stem Bark Hexane, Dichloromethane, and Methanolic Ekstract. Pharmacog J. 2021;13(1): 139-41. 
medium supplemented with $10 \% \mathrm{v} / \mathrm{v}$ Fetal Bovine Serum (Sigma), $1 \%$ antibiotic-antimycotic (GIBCO). Cell suspensions (5x104 cells/ $\mathrm{ml}$ ) were seeding to each well and the cells were incubated for at $37^{\circ} \mathrm{C}$ under $5 \% \mathrm{CO}_{2}$. After 24 hours, extracts were added and microscopic observation was conducted after 24 hour incubation.

\section{RESULT AND DISCUSSION}

\section{Antioxidant assay}

The observed $\mathrm{IC}_{50}$ value from hexane, dichloromethane, and methanol extract were $88.33 \pm 0.19 \mu \mathrm{g} / \mathrm{mL}, 74,54 \pm 0,61 \mu \mathrm{g} / \mathrm{mL}$, and $94.1 \pm 0.19$ $\mu \mathrm{g} / \mathrm{mL}$ respectively. It shows that dichloromethane extract has better antioxidant activity than methanol extract, whereas hexane extract is inactive due to the high content of non-polar compounds such as fatty acid compounds. These results are in accordance with the antioxidant test. According to Nurul Jadid dkk. Anti-oxidant activity range between $50-100 \mu \mathrm{g} / \mathrm{mL}$ exhibit mild anti-oxidant activity. The possibility of these results is due to the phytochemical content that exists are alkaloids, saponins, and glycosides. Based on the literature, the most antioxidant properties found in flavonoids and some of the alkaloids ${ }^{6}$. In Blumeodendron toxbrai plants there are only alkaloids, saponins, and glycosides so that the results of measurement of antioxidant activity indicate an intermediate level.

\section{Cytotoxic assay}

From hexane crude extract, dichloromethane, and methanol extract represented effects on MCF-7 with $\mathrm{IC}_{50}$ values of $121.24 \pm 0.15 \mu \mathrm{g} / \mathrm{mL}$, $55 \pm 0,48 \mu \mathrm{g} / \mathrm{mL}$, and $70.71 \pm 0.15 \mu \mathrm{g} / \mathrm{mL}$. It showed dichloromethane extract was good cytotoxic activity against breast cancer cell line MCF-7 which better than hexane and methanolic extract, whereas Blumemodendron toksbraii showed very low cytotoxicity. The test results showed dichloromethane showed inhibitory activity of cancer cell growth because it had a value in accordance with the criteria where the $\mathrm{IC}_{50}$ value was below $100 \mu \mathrm{g} / \mathrm{mL}$, while hexane extract is inactive because it has an $\mathrm{IC}_{50}$ value above $100 \mu \mathrm{g} / \mathrm{mL}$. A compound is categorized into a potential cytotoxic compound if it has an $\mathrm{IC}_{50}$ value $<100 \mu \mathrm{g} / \mathrm{mL}$, has moderate cytotoxic activity if the $\mathrm{IC}_{50}$ value is in the range of $100-1000 \mu \mathrm{g} / \mathrm{mL}$, and has no cytotoxic activity if the $\mathrm{IC}_{50}$ value is $>1000 \mu \mathrm{g} / \mathrm{mL}^{7}$. Hexane extract also contains non-polar compounds such as fatty acid compounds. This hexane extract does not have strong antioxidant or cytotoxic activity because the main content of hexane extract is fatty acids. Semipolar and polar extracts like dichloromethane and methanol are thought to contain more phenol compounds ${ }^{8}$. Increase or decrease in antioxidant $\mathrm{IC}_{50}$ values is positively correlated with increase / decrease in anticancer $\mathrm{IC}_{50}$ values. The higher the $\mathrm{IC}_{50}$ value of antioxidant activity, the higher the $\mathrm{IC}_{50}$ value of anticancer activity. The content of phenolic compounds can increase the inhibitory effect on cancer cells? ${ }^{9}$. This is consistent with the results obtained in this study, in which the antioxidant extract of dichloromethane extract had $\mathrm{IC}_{50} 74.54 \mu \mathrm{g} / \mathrm{mL}$ and $\mathrm{IC}_{50}$ for anti-cytotoxic is $55 \mu \mathrm{g} / \mathrm{mL}$.

\section{CONCLUSION}

Blumeodendron toksbraii has show good antioxidant and cytotoxicity based on bioassay result from dichloromethane extract. From dichloromethane extract, it show 74,54 $\pm 0,61 \mu \mathrm{g} / \mathrm{mL}$ for antioxidant assay and $55 \pm 0,48 \mu \mathrm{g} / \mathrm{mL}$ for cytotoxic assay. Futher attempt needed to isolate compound from dichloromethane extract which show good anti-oxidant and cytotoxic assay from this plant.

\section{ACKNOWLEDGEMENTS}

This study was supported by Research Centre for Chemistry-LIPI. Cancer cell line MCF 7 bioassay was conducted from Mrs. Nina Artanti, RCC-LIPI. Blumeodendron toksbraii plant materials was provided by Bogor Botanical Garden. .

\section{CONFLICTS OF INTEREST}

The authors declare that there are no conflicts of interest in this study.

\section{REFERENCES}

1. GBD 2015 Risk Factors Collaborators. Global, regional, and national comparative risk assessment of 79 behavioural, environmental and occupational, and metabolic risks or clusters of risks, 1990-2015: a systematic analysis for the Global Burden of Disease Study 2015. Lancet. 2016 Oct; 388 (10053):16591724.

2. Adams JD, Flora KP, Goldspiel BR, et al. Taxol: a history of pharmaceutical development and current pharmaceutical concerns. Journal of the National Cancer Institute. Monographs. 1993 (15):141-147

3. Agusta, A. \& Chairul, Tumbuhan dan Senyawa Bioaktif yang Memiliki Potensi Sebagai Anti Virus HIV [Plants and Active Compounds that have potential as antiviral HIV]. Indonesian Journal of Pharmacy.1995, 6 (1): $20-30$

4. Elya, B. et al. Screening of a-glucosidase inhibitory activity from some plants of Apocynaceae, Clusiaceae, Euphorbiaceae, and Rubiaceae, Journal of Biomedicine and Biotechnology, 2012. doi: 10.1155/2012/281078.

5. G. Yen and H. Chen Antioxidant Activity of Various Tea Extracts in Relation to Their Antimutagenicity, Journal of Agriculture and Food Chemistry. 1995, 43:2732

6. .Zhang YJ, Gan RY, Li S, et al. Antioxidant Phytochemicals for the Prevention and Treatment of Chronic Diseases. Molecules. 2015, 20(12):21138-21156.

7. Prayong P., Barusrux S. and Weerapreeyakul N., Cytotoxic activity screening of some indigenous Thai plants, Fitoterapia, 2008, 79(7-8):598-601.

8. Barchan, A. \& Bakkali, M. \& Arakrak, Abdelhay \& Pagán, Rafael \& Laglaoui, Amin. The effects of solvents polarity on the phenolic contents and antioxidant activity of three Mentha species extracts. International Journal of Current Microbiology and Applied Sciences. 2014, 3:399-412

9. Tsiapara AV, Jaakkola M, Chinou I, Graikou K, Tolonen T, Virtanen V, Moutsatsou P. Bioactivity of Greek honey extracts on breast cancer (MCF-7), prostate cancer (PC3) and endometrial cancer (Ishikawa) cells: profile analysis of extracts. Food Chemistry. 2009, 116(3): 702708 


\section{GRAPHICAL ABSTRACT}

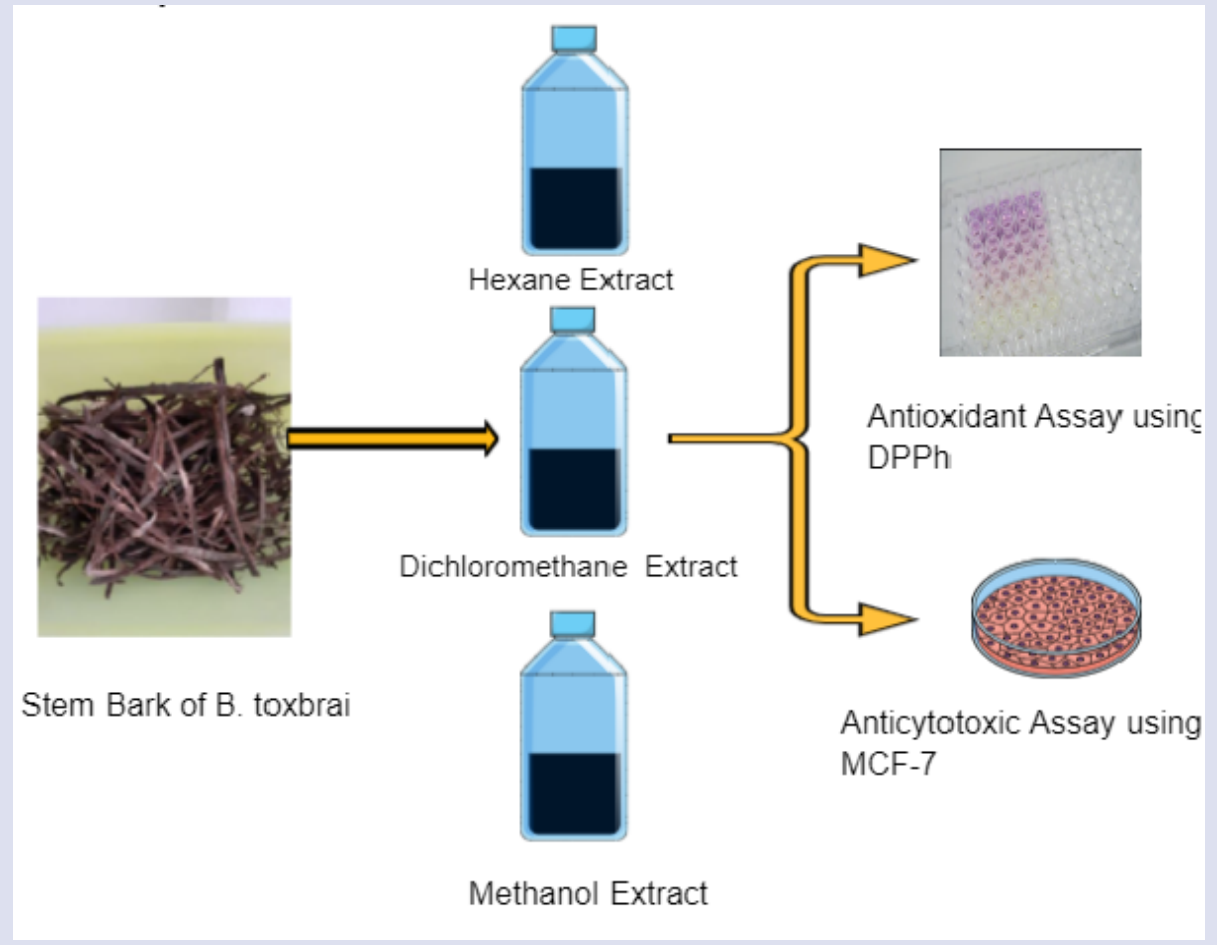

\section{ABOUT AUTHORS}

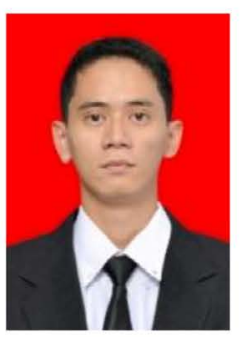

Andreas Susilo Adi is Magister Pharmacy Student at the

Faculty of Pharmacy, Universitas

Indonesia, Kampus UI Depok, West Java 16424, Indonesia.

$\mathrm{He}$ has research experience in the field of Biology

Pharmacy.

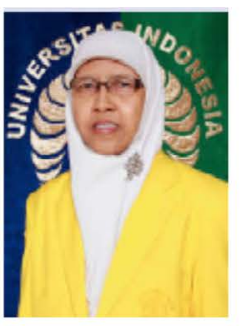

Berna Elya is a Professor and Lecturer at the Faculty of

Pharmacy, Universitas Indonesia, Kampus UI

Depok, West Java 16424, Indonesia. She develops works

in the area of Pharmacognosy, Phytochemistry,

and Natural Product.

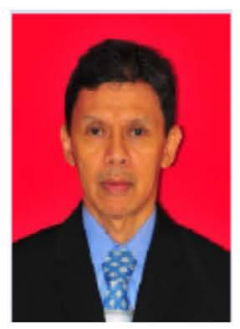

Muhammad Hanafi is a Researcher at the Research Center for Chemistry, Indonesian Institute of Sciences,

PUSPITEK area, Serpong, South Tanggerang, Banten, Indonesia and Lecturer at the Faculty of Pharmacy, University of Pancasila, Srengseng Sawah, Jakarta, Indonesia.. He has research experience in the field of Natural Product. 